\title{
Pengaruh Rendaman Air Laut Pasang Surut terhadap Campuran Lapis Aspal Beton AC-WC dengan Modifikasi Steel slag Ramah Lingkungan
}

\author{
Emil Adly ${ }^{a *}$, Farras Luthfir Rahman ${ }^{\mathrm{a}}$ \\ ${ }^{a}$ Program Studi Teknik Sipil, Fakultas Teknik, Universitas Muhammadiyah Yogyakarta
}

Riwayat Artikel

Diserahkan

4 Februari 2021

Direvisi

13 Agustus 2021

Diterima

19 Agustus 2021

*Penulis korespondensi emil@umy.ac.id

\begin{abstract}
Abstrak
Perkerasan jalan yang terletak di daerah pantai memiliki peluang lebih besar terendam air laut. Di sepanjang jalan Pantai Utara khususnya di Jalan Kaligawe Raya, Semarang, Jawa Tengah kerap terjadi banjir air laut pasang (ROB). Perkerasan jalan yang terendam oleh air memiliki potensi yang tinggi untuk mengalami kerusakan, karena air merupakan salah satu faktor penyebab kerusakan pada perkerasan jalan, ditambah dengan repetisi beban yang berulang-ulang akan menurunkan umur rencana, sehingga jalan lebih cepat mengalami kerusakan akibat menahan beban lalu lintas. Penelitian ini bertujuan untuk menginvestigasi campuran perkerasan apal dengan menggunakan steel slag yang direndam dengan air laut dengan durasi air laut 6, 12 dan 24 jam dan diuji dengan menggunakan marshall test. Hasil pengujian didapatkan nilai karakteristik marshall berupa density, VFA (Void Filled Asphalt), stabilitas, VIM (Void In the Mix), VMA (Void in Mineral Agregate) memenuhi kriteria standar kecuali nilai flow.
\end{abstract}

Kata-kata kunci: air laut pasang surut, marshall, perkerasan lentur, steel slag

\section{Abstract}

Road pavement near coastal area has greater chance for seawater immersion. Along the road of Pantai Utara especially on Jalan Kaligawe Raya, Semarang, Jawa Tengah, tidal seawater flood often occurs. Road pavement that is immersed by water is potentially damaged since water is one of the causing factors of damage in road pavement. Recurring weight also will decrease the design life and the road degrades faster. This study aims to investigate the asphalt pavement mixture using steel slag soaked in seawater with a duration of 6,12 and 24 hours and tested using the Marshall test. The test results showed that the marshall characteristic values in the form of density, VFA (Void Filled Asphalt), stability, VIM (Void In the Mix), VMA (Void in Mineral Aggregate) met the standard criteria except the flow value.

Keywords: flexible pavement, marshall, steel slag, tidal seawater.

\section{PENDAHULUAN}

Jalan merupakan prasarana yang sangat penting dalam transportasi darat yang dilalui oleh kendaraan bermotor, mobil, hingga truk. Jalan memiliki peran fundamental yang penting bagi masyarakat guna memenuhi kebutuhan ekonomi dan sosial. Kondisi jalan yang baik akan meningkatkan mobilitas masyarakat. Namun dalam perawatan jalan terdapat permasalahan akan perkerasan jalan yang terendam oleh air laut. Air yang tergenang lama di permukaan perkerasan jalan akan mempercepat umur rencana yang menyebabkan kerusakan pada jalan Di Jl. Kaligawe Raya, Semarang, Jawa Tengah marak terjadi banjir pasang air laut (rob) menjadi salah satu penyebab rusaknya jalan. Karena air laut yang merusak jalan bisa terus menerus menjadi masalah bagi perkerasan jalan. menurut Peraturan Pemerintah nomor
101 tahun 2014 tentang pengelolaan limbah B3 tidak hanya jalan rusak yang meresahkan lingkungan, di sisi lain terdapat limbah industri B3 (Bahan Berbahaya dan Beracun) sisa hasil pengolahan baja menjadi alternatif digunakan sebagai bahan pengganti agregat (Sentosa dkk., 2010; Nahyo dkk., 2015; Setiadji dkk., 2017).

Dirasa perlu adanya pengujian mengenai dampak dari rendaman air laut dan pengelolaan limbah dengan baik menjadi alternatife untuk menggunakan steel slag sebagai bahan pengganti agregat (Suhardi dkk., 2016; Bahri dkk., 2010).

Limbah ramah lingkungan steel slag pada campuran aspal beton dan dilakukan rendaman air laut, karena perannya dalam perkerasan jalan dapat menurunkan umur rencana perkerasan jalan (Hartati dkk., 2009; Pramudya dkk., 2013). 
Pengaruh dari air laut yang diambil di pesisir Pantai Utara tepatnya di Pelabuhan Tanjung Emas Semarang terhadap campuran material modifikasi menggunakan steel slag sebagai pengganti agregat menyebabkan karakteristik pada marshall tidak baik (Fahmi dkk., 2017; Muaya dkk., 2015). Dengan variasi steel slag dan durasi perendaman yang berbeda, peneliti ingin menginvestigasi sejauh mana resistensi kekuatan campuran aspal dengan material modifikasi yang diuji dengan menggunakan marshall test karena menurut Setiadji dkk., (2017), semakin lama campuran aspal direndam dengan pasang surut air laut maka memiliki dampak kimia yang besar pada pengujian marshall

\section{METODE PENELITIAN}

\subsection{Bahan}

\section{Agregat Kasar}

Agregat kasar yang digunakan berupa batu pecah yang berasal dari daerah Clereng dengan ukuran butiran yang tertahan saringan nomor 8 atau 2,36 mm.

\section{Agregat Halus}

Agregat halus yang digunakan adalah pasir alami yang lolos dari saringan nomor 8 dengan ukuran 2,36 mm yang berasal dari Sungai Progo.

\section{Aspal}

Aspal dengan penetrasi 60/70 dikeluarkan oleh PT Pertamina

\section{Steel Slag}

Steel slag adalah sebuah limbah atau bahan sisahasil pengecoran besi, bentuknya yang menyerupai batu, limbah ini tidak kalah keras juga dari batuan pada umumnya1 (Hartati dkk., 2009; Pramudya dkk., 2013). Digunakan steel slag yang beasal dari PT.Krakaatau Steel Cilegon Banten. Pada penelitian ini menggunakan campuran AC-WC, dan pergantian material agregat dapat dilihat pada Table 1.

Tabel 1. Jumlah dan variasi benda uji

\begin{tabular}{ccc}
\hline Variasi kadar steel slag & Laston & Keterangan \\
\hline $100 \%$ Halus, $50 \%$ kasar & 2 & Tidak Terendam \\
\hline \multirow{2}{*}{$100 \%$ Halus, $50 \%$ kasar } & 2 & Terendam 6 jam \\
\cline { 2 - 3 } & 2 & Terendam 12 jam \\
\cline { 2 - 3 } & 2 & Terendam 24 jam \\
\hline TOTAL & 8 sampel & \\
\hline
\end{tabular}

\section{Air dan Perendaman}

Air laut berasal dari Pelabuhan Tanjung Emas, Semarang, Jawa Tengah. Sampel direndam dengan metode kontinyu pada durasi 6,12 , dan 24 jam sebelum diuji marshall. Dari Table 2, 3, dan 4, pemeriksaan agregat ini memenuhi spesifikasi dari persyaratan yang diharuskan, sehingga bahan dasar pada pengujian diperbolehkan untuk campuran aspal.
Tabel 2. Hasil Pengujian Aspal

\begin{tabular}{clcccc}
\hline No. & Jenis Penguiran & Satuan & Hasil & Persvaratan & Standar \\
\hline 1 & Penetrasi & $\mathrm{mm}$ & 64,4 & $60-69$ & SNI 06-2456-1991 \\
2 & Titik Lembek & ${ }^{\circ} \mathrm{C}$ & 52,5 & $48-58$ & SNI 06-2434-1991 \\
3 & Berat Jenis & - & 1,08 & Min. 1,0 & SNI 06-2441-1991 \\
4 & Kehilangan Berat & $\%$ & 0,13 & Max. 1 & SNI 06-2441-1991 \\
5 & Daktilitas & $\mathrm{cm}$ & 154,75 & $100-200$ & SNI 06-2432-1991 \\
\hline
\end{tabular}

Tabel 3 Hasil Pengujian Agregat Kasar dengan Agregat Halus

\begin{tabular}{|c|c|c|c|c|c|}
\hline No & Jenas Pengujian & Satuan & Hast & Spesifikast & Standar \\
\hline & & $I$ & Kasar & & \\
\hline 1 & $\begin{array}{l}\text { Berat Jenis: } \\
\text { Bulk (Sd) }\end{array}$ & - & 2,9 & $\geq 2,5$ & SNI 03-1969-1990 \\
\hline 2 & $\begin{array}{l}\text { Bernt Jenis } \\
\text { Jenuh Kering } \\
\text { Permmakaan ( }\left(S_{1}\right)\end{array}$ & . & 2,95 & 22,5 & SNI 03-1969-1990 \\
\hline 3 & $\begin{array}{l}\text { Beran Jenis } \\
\text { Apparaant (Sa) }\end{array}$ & - & 3.05 & $\geq 2,5$ & SN103-1969-1990 \\
\hline 4 & $\begin{array}{l}\text { Penyetapan Air } \\
\text { (Sw) }\end{array}$ & $\mathbf{5}$ & 1.87 & $\leq 3$ & SN1 03-1969-1990 \\
\hline 5 & $\begin{array}{l}\text { Abrasi Lor } \\
\text { Angeles }\end{array}$ & $\%$ & $\begin{array}{c}32,3 \\
5\end{array}$ & $\leq 40$ & SNI 03-2417-1991 \\
\hline \multirow[t]{2}{*}{6} & $\begin{array}{l}\text { Kelekatan } \\
\text { Agregat } \\
\text { tethudap Aspal }\end{array}$ & $\%$ & 98 & 295 & SNI 03-2439-1991 \\
\hline & & II & Halus & & \\
\hline 1 & $\begin{array}{l}\text { Berat Jenis } \\
\text { BuII (Sd) }\end{array}$ & $=$ & 3,35 & $\geq 2,5$ & SNI 03-1969-1990 \\
\hline 2 & $\begin{array}{l}\text { Betat Jenis } \\
\text { Jenuh Kering } \\
\text { Permulaan (Ss) }\end{array}$ & - & 3,42 & 22,5 & SNI 03-1969-1990 \\
\hline 3 & $\begin{array}{l}\text { Berat Jenis } \\
\text { Alparegant }\left(S_{a}\right)\end{array}$ & - & 3,59 & 22,5 & SNT 03-1969-1990 \\
\hline 4 & $\begin{array}{l}\text { Penyerapan Air } \\
(\mathrm{Sw})\end{array}$ & $\%$ & 1,98 & 53 & SNI 03.1969.1990 \\
\hline
\end{tabular}

Tabel 4 Hasil Pengujian Steel Slag sebagai agregat halus dan kasar

\begin{tabular}{|c|c|c|c|c|c|}
\hline No. & Jenis Pengujian & Satuan & Hanil & Spcoifikasi & Standar \\
\hline \multicolumn{6}{|c|}{ I. Agrequat Kasar } \\
\hline$T$ & Berat Jenis Balk (Sd) & - & 2515 & $\geqslant 2,5$ & SNI 03-1969-1990 \\
\hline 2 & $\begin{array}{l}\text { Berat Jenis Jenuh } \\
\text { Kering Pernmikaan (Ss) }\end{array}$ & - & 2.59 & $\geq 2.5$ & SNI 03-1969-1990 \\
\hline 3 & $\begin{array}{l}\text { Berat Jenis Appartant } \\
\text { (Sa) }\end{array}$ & $=$ & 2,705 & $\geq 2,5$ & SNI 03-1969-1990 \\
\hline 4 & Penyerapan Air (Sw) & \% & 2,6 & $\$ 3$ & SNI $013-1969.1990$ \\
\hline 5 & Abrasi Las Angeles & $\%$ & 16,49 & $\leq 40$ & SNI 03-24!7-199! \\
\hline \multicolumn{6}{|c|}{ II. Agregat Halus } \\
\hline I & Bent Jenis Balk (Sd) & 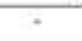 & 2,52 & 22.5 & SNI 03-1969-1990 \\
\hline 2 & $\begin{array}{l}\text { Berat Jenis Jenuh } \\
\text { Kering Persmukaan (Ss) }\end{array}$ & - & 2,59 & $\geq 2.5$ & SNI03-1969-1990 \\
\hline 3 & $\begin{array}{l}\text { Berat Jenis Apparrant } \\
\text { (Sa) }\end{array}$ & - & 2,72 & $\geq 2.5$ & SNI 03-1969-1990 \\
\hline 4 & Penyerapan Air (Sw) & $\%$ & 3,0 & $\$ 3$ & SNI 03-1969-1990 \\
\hline \multicolumn{6}{|c|}{ III. Filier } \\
\hline & Benat Jenis Filler & - & 2.59 & $\geq 2.5$ & SNI 03-4142-1996 \\
\hline
\end{tabular}

\subsection{Prosedur pengujian Pembuatan benda Uji}

Agregat dan steel slag dimasukkan ke dalam wadah yang dipanaskan di atas kompor dengan suhu $160^{\circ} \mathrm{C}$ lalu diberikan sejumlah aspal dengan kadar yang sudah ditentukan dan dimasak merata. Masukkan ke dalam cetakan (mold) 4 inch yang sudah dipanaskan dan dilapisi dengan oli supaya saat mengeluarkan aspal pada cetakan tidak susah dan tidak rusak. Tusuk dengan spatula sebanyak 15 kali pada bagian tepi cetakan dan 10 kali tusukan pada sisi bagian tengah di tiap $1 / 3$ isi campuran aspal panas. Setelah terisi penuh, masukkan campuran 
aspal beserta cetakan ke dalam mesih penumbuk, lalu tumbuk bagian sisi atas cetakan sebanyak 75 kali dan dibalik untuk menumbuk sisi lainnya sebanyak 75 kali. Diamkan selama 24 jam dan dapat diuji marshall.

Pada perencanaan campuran, penentuan optimum komposisi aspal pertama kali dilakukan dengan menggunakan pengukuran, 4,5\%, 5\%, 5,5\%, 6\% dan $6,5 \%$ dari total agregat. Sebanyak 10 sampel berasal dari atas pengukuran, masing-masing sampel duplo.

Tabel 4. Hasil Pengujian Kadar Aspal Optimum

\begin{tabular}{|c|c|c|c|c|c|c|c|}
\hline \multirow[b]{2}{*}{ No } & \multirow[b]{2}{*}{ Kriteria } & \multirow[b]{2}{*}{ Spesifikasi } & \multicolumn{5}{|c|}{ Kadar Aspal (\%) } \\
\hline & & & 4.5 & 5 & 5.5 & 6 & 6.5 \\
\hline 1 & Density & $\mathrm{gr} / \mathrm{cm}$ & & & & & \\
\hline 2 & VFA & Min. $65 \%$ & & & & & \\
\hline 3 & VIM & $3 \%-5 \%$ & & & & & \\
\hline 4 & VMA & Min. $15 \%$ & & & & & \\
\hline 5 & Stability & Min. $800 \mathrm{~kg}$ & & & & & \\
\hline 6 & Flow & $2-4 \mathrm{~mm}$ & & & & & \\
\hline 7 & MQ & $\operatorname{Min} 250 \mathrm{Kg} / \mathrm{mm}$ & & & & & \\
\hline
\end{tabular}

Dari Tabel 4, kadar aspal optimum yang dapat dipakai adalah 5\% dan 5,5\%, karena dari 7 aspek diatas memenuhi persyaratan Bina Marga (2010) pada 2 kadar tersebut, sehingga penelitian ini digunakan kadar aspal optimum 5,25\% karena pengambilan pada titik tengah di antara 2 kadar tersebut.

\section{Pengujian Marshall}

Ukur dimensi dan berat benda uji, rendam selama 30 menit ke dalam bak perendam yang sudah diatur suhunya sebesar $60^{\circ} \mathrm{C}$, lalu rendam dengan air laut sesuai dengan variasi rendaman yang ditentukan, letakkan pada alat uji marshall. Pengujian ini dimaksudk untuk mengetahui dampak perendaman dengan air, terkena terik matahari dan terendam air laut.

\section{Density}

Sering disebut kepadatan yang artinya adalah rasio antara berat benda uji kering terhadap volume benda uji tersebut. Semakin tinggi nilai dari densitas akan menyebabkan nilai stabilitas meningkat (Sentosa dkk., 2010).

\section{Void Filled Asphalt (VFA)}

Persen rongga pada agregat biasa disebut Void Filled Asphalt (VFA) yakni rongga yang diisi aspal tapi aspal yang mengisi tersebut tidak termasuk dengan aspal yang diserap oleh agregat. Jika nilai VFA atau rongga udara yang terisi aspal terlalu besar akan menyebabkan bleeding pada campuran aspal. Dengan batas min 65\%, jika nilainya kecil maka akan menyebabkan campuran aspal tersebut menjadi lebih kedap terhadap air.

\section{Void In Mix (VIM)}

Void In Mix adalah nilai rongga pada campuran aspal panas dengan satuan persen. Rongga tersebut diperlukan untuk ruang bagi material campuran seperti sifat elastisnya. Nilai rongga dalam campuran ini dipengaruhi beberapa faktor, yaitu ukuran agregat yang digunakan, lalu kadar aspal pada campuran dan nilai dari density.dengan batas 3\%-5\%, apabila nilai dari rongga ini terlalu besar dapat menyebabkan lapisan pada perkerasan teroksidasi atau mengalami penuaan aspal sehingga udara dapat mudah masuk.

\section{Void in Minelar Agregate (VMA)}

Rongga dalam mineral agregat (Void in Minelar Agregate) adalah rongga-rongga udara yang diisi oleh aspal dalam campuran aspal yang sudah dipadatkan dengan batas minimal 15\%. Dan rongga-rongga tersebut termasuk rongga yang sudah diisi oleh aspal. Besar nilai rongga ini dipengaruhi oleh beberapa faktor, diantaranya adalah kadaraspal yang digunakan, ukuran fraksi butir agregat, proses pada saat melakukan penumbukan dan penjagaan suhu pada campuran aspal panas.

\section{Stability}

Yaitu kemampuannya perkerasan untuk tahan dalam mendapat beban dari lalu lintas dengan stabil. Maksudnya adalah tidak goyah atau berubah bentuk dan tidak bleeding. Apabila beban dari lalu lintas besar, maka dibutuhkan nilai stabilitas yang tinggi pula untuk menahan beban lalu lintas tersebut. Spesifikasi stability mempunyai batas minimal $800 \mathrm{~kg}$. Nilai stabilitas ini dapat dipengaruhi gesekan dari tiap butiran bahan penyusun, interlocking dari gradasi bahan penyusun dan juga kemampuan kohesi lapisan aspal harus baik. proses pada saat pemadatan juga sangat berpengaruh dalam mendapatkan nilai stabilitas ini (Sukirman, 1995).

\section{Flow}

Flow adalah keadaan dimana suatu campuran memiliki batas optimum untuk hancur, dengan batas 2-4 $\mathrm{mm}$, nilai flow yang tinggi menandakan bahwa campuran yang diuji bersifat plastis, apabila kecil campuran tersebut adalah kaku. Dan yang dapat mempengaruhi dari nilai deformasi ini adalah ukuran butir bahan penyusun yang digunakan, penentuan kadar aspal dan ketetapan suhu pada saat melakukan pemadatan (Muaya dkk., 2015).

\section{Marshall Quotient (MQ)}

Nilai antara hasil bagi antara nilai stabilitas terhadap nilai kelelehan (flow). Batas minimal $\mathrm{mq}$ adalah $250 \mathrm{~kg} / \mathrm{mm}$, dan jika didapati nilai MQ besar, maka campuran aspal keras akan menjadi lebih kaku, berlaku juga untuk kebalikannya yaitu jika didapatkan nilai MQ menjadi lebih kecil maka perkerasan tersebut dapat berisiko lentur.

\section{HASIL DAN PEMBAHASAN}

\subsection{Density}

Beberapa faktor yang dapat mempengaruhi density antara lain berat jenis agregat, kadar aspal, gradasi aspal, kualitas penyusun dan proses pemadatan yang meliputi temperatur dan besarnya tumbukan (Adly dkk., 2019)

Gambar 1 menunjukkan nilai density (kepadatan) pada campuran aspal yang direndam air laut menunjukkan peningkatan setelah direndam. Nilai maksimum density sebesar $2.394 \mathrm{gr} / \mathrm{cm}$ pada $12 \mathrm{jam}$, selanjutnya terjadi penurunan setelah 24 jam 
perendaman. Sangat jelas bahwa menggunakan steel slag dengan kondisi terendam air laut membuat density campuran aspal tetap baik karena tidak ada persyaratan yang mengatur untuk batas minimal dan maksimal dari nilai ini.

\subsection{VFA}

Gambar 2 menunjukkan hasil pengujian VFA pada rendaman air laut 0 jam senilai 72,09 dan mengalami peningkatan pada rendaman air laut 6 jam menjadi $75,49 \%$ dan naik lagi hingga puncak nilai tertinggi pada perendaman 12 jam yaitu $76,26 \%$. Setelah lama perendaman pada 24 jam nilai VFA menurun menjadi 74,46\%. Dapat diketahui jika campuran aspal tersebut direndam denganair laut nilai VFA akan naik, dan pada akhirnya akan turun pada perendaman setelah $12 \mathrm{jam}$. Seperti yang diatur pada spesifikasi umum Bina Marga (2010) revisi 3 jika nilai VFA > 65\% maka campuran aspal yangdigunakan memenuhi syarat yang diatur.

\subsection{VIM}

Dapat dilihat pada Gambar 3, nilai peresentase nilai VIM dari rendaman air normal mengalami penurunan yaitu dari $4.47 \%$ menjadi $3,77 \%$ dan terus menurun pada rendaman 12 jam yaitu sebesar 3,63\% dan uniknya, setelah pada rendaman 24 jam persentase VIM meningkat menjadi 4,01\%. Grafik ini menunjukkan bahwa lama perendaman air laut pada campuran aspal modifikasi dengansteel slag ini menyebabkan nilai rongga dalam campuran menjadi lebih kecil, dan membesar pada saat rendaman lebuh lama. Namun persentase hasil campuran masuk dalam spesifikasi yang disyaratkan adalah antara 3\% hingga 5\%.

\subsection{VMA}

Gambar 4 menunjukkan nilai rongga dalam mineral agregat pada kondisi tanpa perendaman air laut memiliki nilai tertinggi yakni $16 \%$ namun menurun pada waktu rendaman 6 jam dan 12 jam yaitu $15.4 \%$ dan $15.27 \%$ dan meningkat lagi pada durasi perendaman selama 24 jam yakni sebesar $15.6 \%$. namun dari hasil yang didapatkan masih masuk dalam spesifikasi umum Bina Marga (2010) revisi 3 syarat besarnya nilai VMA >15\%.

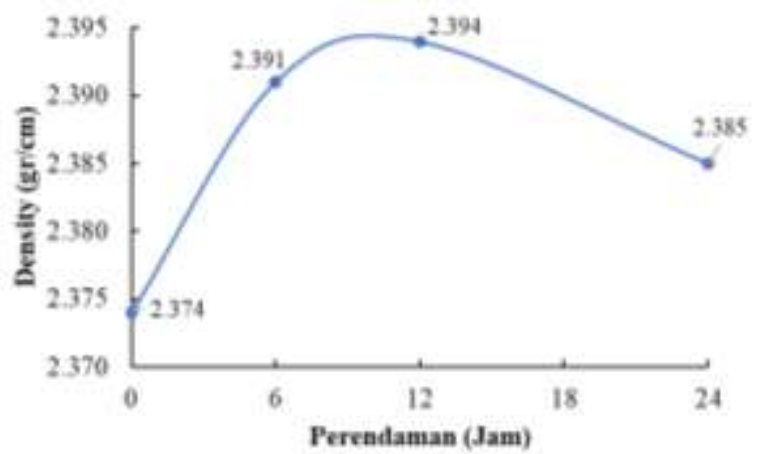

Gambar 1 Grafik hubungan kepadatan dengan rendaman

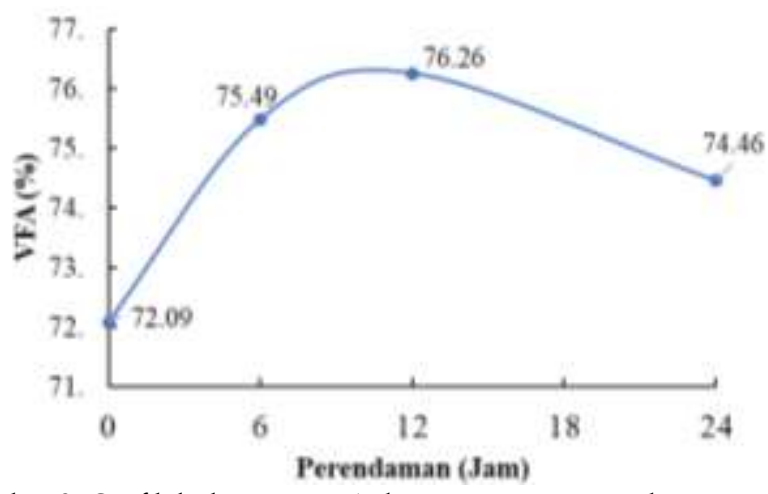

Gambar 2. Grafik hubungan VFA dengan intensitas rendaman

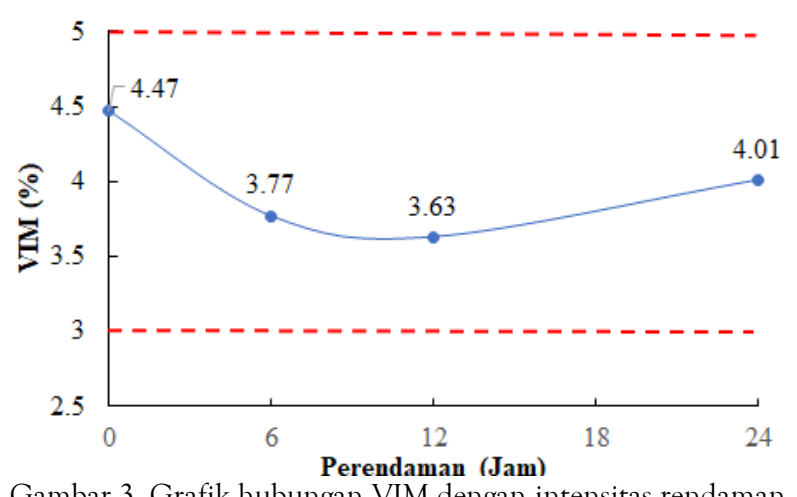

Gambar 3. Grafik hubungan VIM dengan intensitas rendaman

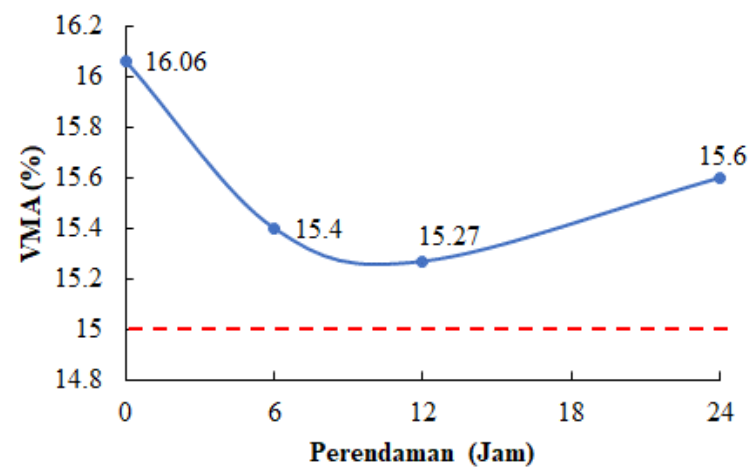

Gambar 4. Grafik hubungan VIM dengan intensitas rendaman

\subsection{Stability}

Kadar aspal yang digunakan dan penjagaan suhu hingga proses pada saat pemadatan juga sangat berpengaruh dalam mendapatkan nilai stabilitas. Gambar 5 menunjukkan nilai stabilitas mengalami peningkatan nilai perendaman setelah 6 jam dan 12 jam yaitu sebesar $2140,52 \mathrm{Kg}$ dan $2275,11 \mathrm{Kg}$, lalu mengalami sedikit penurunan pada perendaman selama 24 jam yaitu sebesar 2226,37 Kg. nilai stabilitas terendah ada pada tanpa perendaman air laut, dan nilai tertinggi ada pada perendaman waktu 12 jam. Namun masih memenuhi spesifikasi diatas $800 \mathrm{~kg}$.

Nilai stabilitas danwaktu perendaman dengan air laut memiliki hubungan yang berbanding terbalik, apabila perendaman semakin lama nilai stabilitas menurun (Nahyo dkk., 2015; Pratama dkk., 2017) hal ini disebabkan karakteristik steel slag yang menyerap suhu 
lebih cepat dari batu kasar. Oleh karena itu, pada 24 jam selama pengujian, bahan menjadi dingin dan kasar.

\subsection{Flow}

Gambar 5 menunjukkan nilai kelelehan yang diperoleh pada pengujian menggunakan rendaman air laut mendapatkan penurunan bila dibandingkan dengan benda uji tanpa rendaman air laut. Flow terendah pada 6 jam perendaman sebesar $0,81 \%$ selanjutnya meningkat lambat dan masih berada pada batas minimum spesifikasi yakni $2 \%$.

Dari hasil yang tidak memenuhi spesifikasi yang ditentukan jelas sekali menandakan bahwa campuran aspal menggunakan steel slag ini mudah sekali rusak akibat air laut. Hal ini disebabkan oleh menurunnya daya rekat aspal terhadap agregat akibat keasaman air laut. Fahmi dkk., (2017) menyatakan bahwa semakin lama campuran aspal beton terendam air laut dapat membuat kerapatan campuran berkurang, baik dari sisi adhesi maupun kohesi, hal ini disebabkan oleh pengaruh gaya tekan air (water preasure) dalam campuran.

\subsection{Marshall Quotient (MQ)}

Gambar 6 menunjukkan hasil marshall quotient terhadap perendaman air laut dengan hasil di atas spesifikasi yakni $259 \mathrm{~kg} / \mathrm{mm}$. Dari grafik menunjukkan bahwa perendaman selama 6 jam mendapatkan hasil MQ tertinggi sebesar $2797.07 \mathrm{~kg} / \mathrm{mm}$ hal ini menunjukkan bahwa di jam tersebut campuran aspal menjadi leih kaku bila dibandingkan dengan lama perendaman 12 dan 24 jam.

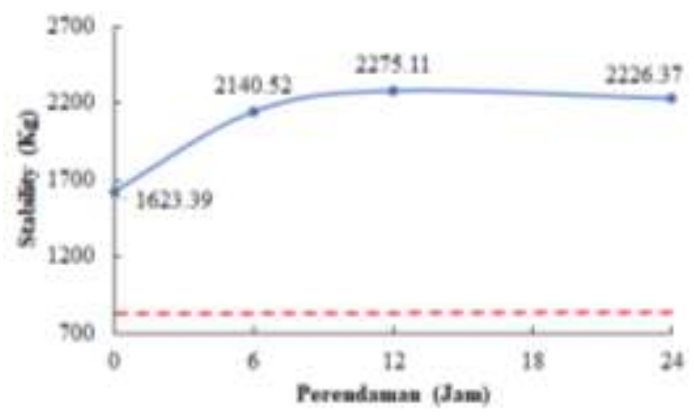

Gambar 4. Grafik hubungan Stability dengan intensitas rendaman

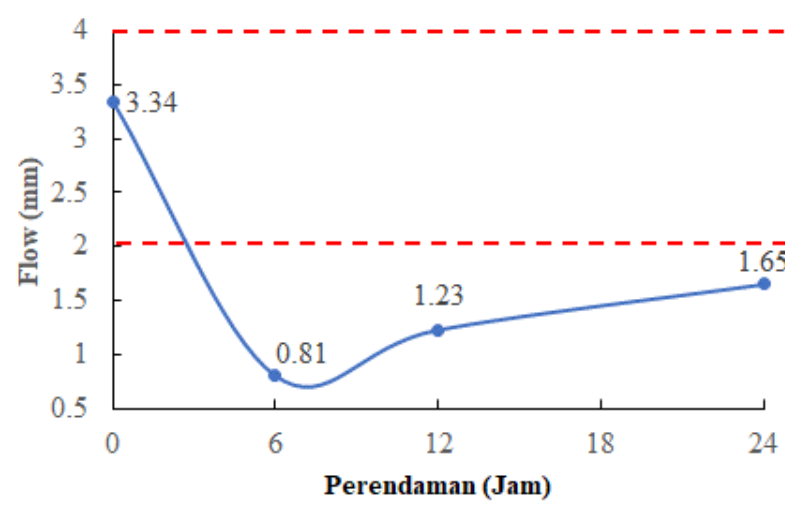

Gambar 5. Grafik hubungan flow dengan intensitas rendaman

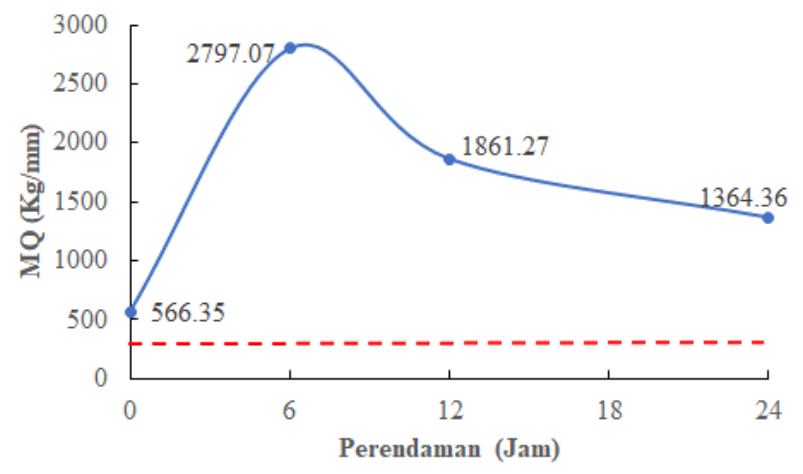

Gambar 6. Grafik hubungan flow dengan intensitas rendaman

\section{KESIMPULAN}

Berdasarkan penelitian yang telah dilakukan, penggunaan steel slag sebagai bahan campuran perkerasan modifikasi memenuhi kualifikasi standar marshall. Di lingkungan air laut karakteristik marshall berupa stability, VIM, VFA, VMA memenuhi kriteria standar kecuali flow, sehingga perkerasan menggunakan modifikasi steel slag ini masih belum layak untuk digunakan, dikarenakan sifat air laut yang mengandung mineral yang bisa merusak durabilitas perkerasan.

\section{DAFTAR PUSTAKA}

Adly, E., Rahmawati, A., \& Firkathi Hidayah, N. (2019). The Performance of AC-WC Asphalt Mixture with Eco-Friendly Steel Slag Against Sea Tidal Impact. Proceedings of the Third International Conference on Sustainable Innovation 2019 - Technology and Engineering (IcoSITE 2019), Yogyakarta, Indonesia.

Bahri, S., dan Irawan, D. A. S., 2014, Pengaruh Limbah Serbuk Besi Sebagai Pengganti Sejumlah Agregat Halus Terhadap Campuran Aspal, Inersia, 1(2), 25 32.

Binamarga, 2010, Spesifikasi Umum (revisi 3), Jakarta, Indonesia.

BSN, 1990a, SNI 03-1968-1990, Metoda Pengujian Analisis Agregat Halus dan Kasar, Badan Standardisasi Nasional, Jakarta.

BSN, 1990b, SNI 03-1969-1990, Metoda Pengujian Berat Jenis dan Penyerapan Agregat Kasar, Badan Standardisasi Nasional, Jakarta.

BSN, 1990c, SNI 03-1970-1990, Metoda Pengujian Berat Jenis dan Penyerapan Agregat Halus, Badan Standardisasi Nasional, Jakarta.

BSN, 1990d, SNI 03-1971-1990, Metoda Pengujian Kadar Air Agregat, Badan Standardisasi Nasional, Jakarta.

BSN, 1990e, SNI 03-2417-1990, Metoda Pengujian Keausan Agregat dengan Mesin Abrasi Los Angeles, Badan Standardisasi Nasional, Jakarta.

BSN, 1990f, SNI 03-4142-1990, Metoda Jumlah Bahan dalam Agregat yang Lolos Saringan No. 200 (0,075 $\mathrm{mm})$, Badan Standardisasi Nasional, Jakarta.

BSN, 1991a, SNI 03-2439-1991, Metoda Pengujian Titik Lembek Aspal, Badan Standardisasi Nasional, Jakarta.

BSN, 1991b, SNI 06-2432-1991, Metoda Pengujian Daktilitas Bahan-bahan Aspal, Badan Standardisasi Nasional, Jakarta. 
BSN, 1991c, SNI 06-2434-1991, Metoda Pengujian Titik Lembek Aspal, Badan Standardisasi Nasional, Jakarta.

Fahmi, R., Saleh, S. M., dan Isya, M., 2017, Pengaruh Lama Rendaman Air Laut Terhadap Durabilitas Campuran Aspal Beton Menggunakan Aspal Pen. 60/70 yang Disubstitusi Limbah Ethylene Vinyl Acetate (EVA), Jurnal Teknik Sipil, 6(3), 271-282.

Fristin Yohana, M., 2009, Studi Pengaruh Steel Slag Sebagai Pengganti Agregat Kasar Pada Campuran Aspal Beton Terhadap Workabilitas Dan Durabilitas, Rekayasa Sipil, 5(1), 20-28.

Hartati, F.Y M., (2009) Studi Pengaruh Steel Slag Sebagai Pengganti Agregat Kasar Pada Campuran Aspal Beton Terhadap Workabilutas Dan Durabilitas, Padang: Politeknik Negeri Padang

Muaya, G. S., Kaseke, O. H., dan Manoppo, M. R., 2015, Pengaruh Terendamnya Perkerasan Aspal oleh Air Laut yang Ditinjau Terhadap Karakteristik Marshall, Jurnal Sipil Statik, 3(8). 562-570.

Nahyo, N., Sudarno, S., dan Setiadji, B. H., 2017, Durabilitas Campuran Hot Rolled Sheet-Wearing Course (HRS-WC) Akibat Rendaman Menerus dan Berkala Air ROB, Teknik Sipil Universitas Abulyatama, 1(2), 141-154.

Peraturan Pemerintah 2014, No.101 tentang Pengelolaan Limbah Bahan Berbahaya dan beracun, Sekretariat Negara, Jakarta, Indonesia.

Pratama, B. A., dan Miftahul Fauziah, S.T., 2017, Perbandingan Kinerja Campuran Hot Rolled
Asphalt (HRA) dengan Bahan Ikat Aspal Pen 60/70 dan Apal Retona Blend 55 dengan Variasi Durasi Rendaman Air Laut, Jurnal

Teknisia, 22(1), 323-332.

Fahmi, R., Saleh, S. M., \& Isya, M. (2017). Pengaruh Lama Rendaman Air Laut Terhadap Durabilitas Campuran Aspal Beton Menggunakan Aspal Pen.60/70 Yang Disubstitusi Limbah Ethylene Vinyl Acetate (Eva). Jurnal Teknik Sipil, 6(3), 2711282

Pramudya, A., Setyawan, A., \& Sarwono, D. (2013). Pengaruh Penambahan Limbah Bubutan Baja Pada Lapis Tipis Campuran Aspal Panas Terhadap Karakteristik Kuat Tarik Tidak Langsung, Kuat Tekan Bebas Dan Permeabilitas. E-Jurnal MATRIKS TEKNIK SIPIL, 1(4), 519-526.

Sentosa, L., \& Erly, L., 2014, Kinerja Marshall Campuran Laston dengan Agregat Bulat dari Sungai Kampar Sebagai Agregat Kasar, Jurnal Asosiasi Perusahaan Teknik Mekanikal dan Elektrikal, 2(1), 86-95.

Setiadji, B. H., dan Utomo, S., 2017, Effect of Chemical Compounds in Tidal Water on Asphalt Pavement Mixture, International Journal of Pavement Research and Technology, 10(2), 122-130.

Suhardi, S., Pratomo, P., dan Ali, H., 2016, Studi Karakteristik Marshall Pada Campuran Aspal Dengan Penambahan Limbah Botol Plastik, Jurnal Rekayasa Sipil dan Desain, 4(2), 284-293.

Sukirman, S., 1995, Perkerasan Lentur Jalan Raya, Bandung, Nova. 